\title{
Contents of Volume 12
}

Árvay, J. and Vértes, A., Impact of the hidden economy on growth rates in Hungary

Aslaksen, I., Fagerli, T. and Gravningsmyhr, H.A., Measuring household production in an input-output framework: the Norwegian experience

Fagerli, T., see Aslaksen, I.

Franks, M.M. and Herzog, A.R., Age and gender differences in productive activity: revisited

García, M., see Planas, J.

Gilomen, H., Towards a social reporting system in Switzerland

Glaude, M., From school to employment and from adolescence to adulthood: the place and limits of social indicators in the study of transitions in young people's lives

Gravningsmyhr, H.A., see Aslaksen, I.

Griffin, T., CES Plenary Session 1994. Points made in discussion of planning and priority setting

Griffin, T., see Mikkelsen, L.

Griffin, T., Mikkelsen, L. and Kalampasut, P., A statistical profile of youth in Europe and North-America

Harala, R., Evaluation of the results of the register-based population and housing census 1990 in Finland

Harala, R., Monitoring young people's transition from school to work: Finnish data resources

Hedman, B., Salaries at the top

Herzog, A.R., see Franks, M.M.

Hoffmann, E., We must use administrative data for official statistics - but how should we use them? 
Kalampasut, P., see Griffin, T.

Kjeldstad, R., Women in powerful positions. The case of Norway

McEwin, M., Social indicators and social statistics in Australia

McLennan, W., Statistical planning and priority setting in the UK Central Statistical Office

Mikkelsen, L. and Griffin, T., International statistical divisions. The Statistical Division of the Economic Commission for Europe

Mikkelsen, L., see Griffin, T.

Noll, H.-H., The digital information system social indicators: a new form of presentation of the German system of social indicators

Pergamit, M.R., Assessing school-to-work transitions in the United States

Petrie, D.B., Canada's National Longitudinal Survey of Children

Planas, J., García, M. and Zaldivar, M., The exclusion of youth: a look at the transition from school to adulthood

Spieker, F., The use of identification numbers to link information from various sources and create alternative statistical units and concepts

Stone, L.O., Utility of integration of data for paid work and unpaid work of economic value - the case of female managers

Taswell, K., see Hoffmann, E.

Thygesen, L., The register-based system of demographic and social statistics in Denmark - an overview

Tuinen, H.K. van, Social indicators, social surveys and integration of social statistics 